\begin{tabular}{c} 
Volume and Issues Obtainable at Center for Sustainability Research and Consultancy \\
Review of Politics and Public Policy in Emerging Economies \\
ISSN: $2708-3829$ (E): 2708-356X \\
Volume 2: No. 1, June 2020 \\
CSRC \\
Journal homepage: $\underline{\text { www.publishing.globalcsrc.org/rope }}$ \\
\hline
\end{tabular}

\title{
The Human Resources Sustainability Debate: Exploring the Role of Operations Management as a Critical Function in an Organisation
}

\section{${ }^{1}$ Sadeeq Garba Abubakar, ${ }^{2}$ Yusuf Ova Mutalib, ${ }^{3}$ Muhammad Zia-Ul-Rahman Abubakar}

${ }^{1}$ Lecturer, Business Administration and Management Department, The Federal Polytechnic, Bauchi, Bauchi State, Nigeria, sadeeqgarbatee@yahoo.com

${ }^{2}$ Lecturer, Accountancy Department, The Federal Polytechnic, Bauchi, Bauchi State, Nigeria, yomuta2002@yahoo.com

${ }^{3}$ Lecturer, Mathematics Department, Bauchi State University Gadau, Bauchi State, Nigeria, ziaulrahman.abubakar@gmail.com

\section{ARTICLE DETAILS \\ History \\ Revised format: May 2020 \\ Available Online: June 2020}

\section{Keywords}

Human resources, Intellectual capital, Knowledge workers, Operations management, Sustainability

\section{JEL Classification}

MO, M1

\section{OPEN ACCESS}

\begin{abstract}
Purpose: The reason of this research endeavour is to address the requirement for the strengthening of Operation Director on how to stand up to the encounter of adjusting the interface and desires of the business with those of the locational associates to attain and keep up production and economical advantage. Methodology: The methodology is a qualitative in nature utilizing hypothetical and theoretical strategies that consolidate a reference list audit to attain the anticipated destinations. Results: The findings from this study is about incorporating the reality that sustainable improvement ought to be taken care of based on productivity with assets, and carefully arranged to provide both prompt and long-term benefits for individuals, planet, and prosperity. Research limitations/implications: A major impediment of utilizing secondary information is that the new user does not know and cannot determine the initial interest taken by the original source that gave guidance to the information collection process and the preparation as well. Generally, it is difficult to know precisely how it was conducted and if the data were affected by difficulties such as low response rate or respondent misunderstanding of specific survey questions. Practical implications: The Operation Directors are those able of creating plans, advancement, and to provide products/services to the markets which are of a lesser amount of ecological disaster. For persistent industry sustainability, an organization need to recognize an individual, his esteem, advance his competence and this should apply to every member of the team. Originality/value: This study contributes to the drive towards exploring the nature of sustainability itself and the critical need for operations management in sustainability management.
\end{abstract}

(C) 2020 The authors, under a Creative Commons AttributionNonCommercial 4.0

Corresponding author's email address: sadeeqgarbatee@yahoo.com

Recommended citation: Abubakar, S. G., Mutalib, Y. O. \& Abubakar, M. Z. R. (2020). The Human 
Resources Sustainability Debate: Exploring the Role of Operations Management as a Critical Function in an Organisation. Review of Politics and Public Policy in Emerging Economies, 2 (1), 19-25

\section{Introduction}

\subsection{Background of the Study}

Slack, Chambers, and Johnston (2003) state that the operations work of the organization is concerned with the course of action of assets committed to generate and convey the organization's products in the form of product and services. Additionally, the plan and administration of operations unequivocally impact how much vitality and material assets are devoured to make products or provide a benefit. Likewise, operations choices are moreover somewhat capable for how effortlessly a thing can be reused, the nature, degree of outflows, and misuses created with respect to merchandise's brand and its use. Hence, the arrangements to numerous regular issues, it causes, is positioned equitably and unequivocally within the operations administration domain.

Agreeing to Neves and Drohomeretski (2014), sustainability could be said to be developing quickly because it picks up significance in different segments of the economy. As a consequence of the contemporary designs in sustainability, the commercial sector is challenged to adjust to novel market requirements and dispositions (Gillet, 2011). Besides, Jabbour and Jabbour (2009) contributed to the debate by stating that such establishments need to add to a decrease in natural effects from their source chains, encouraging expansions in other service outlets' natural implementation strategy. Hence, it becomes necessary to redesign their commercial implementation models, and also corporations began to integrate perceptions and inclinations in sustainability although preserving their obligation to screen and measure performance. Accordingly, Vinodh et al. (2011) suggested that various sustainability activities have been incorporated geared towards supporting feasible enhancement, weakening natural impacts whereas still allowing for business development.

The objective of Human Assets Administration was to make it feasible for an organization to advance its key objectives by choosing, creating, keeping up, and viably handling the human capital as a forefront and treasured constituent of the organization's assets. The strong worldwide competition brought about from globalization and the world developing markets, the innovative progression have made it a requirement for organizations to come up with imaginative and economical administration techniques.

\subsection{Statement of the Problem}

The theory of human capital looked at the value addition an individual contribute to enterprise. Chatzkel (2004) stated that "it is human capital that is the differentiator for organizations and the genuine premise for competitive advantage". Human capital hypothesis, as expressed by Ehrenberg and Smith (cited in Aristocrat and Armstrong 2007), hypothesize labour as demonstrating a set of aptitudes and capabilities which can be "rented out" to employers. The evidence contained in the information possessed by the employee and the talents he has, put together can help to create a guaranteed level of profitability through optimal job performance by the employee. Investment in human assets is an important constituent of the indiscernible resources of the enterprise. The other intangible resources in the same category include copyright, client relations, and brands. The basic issue, in this manner, is to investigate the significance of the industry-wide operations and commercial action and its effects on sustainability.

Based on the aforesaid, the questions below are been asked:

- In what way do organizations utilize their human resources?

- $\quad$ By what method can organizations be encouraged to re-strategize on how to utilize their human asset to guarantee human resources sustainability?

- How can managers adjust the interface of distinctive partners in organizations whereas keeping up a feasible work environment for employees? 


\subsection{Aim of the Study}

The research endeavour is poised to investigate in what way operation supervisory personnel could go up against the tasks of adjusting the interface and requirements of their trade with those of their invaluable asset, to realize and keep up efficiency and competitive advantage over their competitors.

\section{Literature Review}

\subsection{What Sustainability Stands for?}

World Commission on Environment and Development defined sustainability (cited by Wilkinson, Hill and Gollan 2001, p.1492), as a "development that meets the needs of the present without compromising the ability of future generations to meet their own needs". Furthermore, Sutton (1999) stated that for the notion of sustainability to be expressive, hence, it must speak of preserving, reintroducing or reinstating something exact, and this is in furtherance of exploiting the moral scopes of the equality of the exchange between existing economic stress and the imminent necessities of the environment.

The conservative definition of sustainable development stated above could be inclined to be understood otherwise in various situations. Normally, it is ecological sustainability that is the emphasis of consideration, but sustainability is essentially a broader idea encompassing a comprehensive established measure of "quality of life" or "corporate social responsibility" encompassing economic, societal and environmental concerns (Payne and Raiborn (2001), Wilkinson, Hill, and Gollan (2001), Carroll (1991).

\subsection{Sustainable Development}

World Bank (2013) gave a bright outlook of period spanning over two decades, and averred that economic growth has elevated more than 660 million people out of poverty and has raised the income levels of millions more. However, it has come at the detriment of the environment and poor populations. Sustainable development identifies that growth must be both inclusive and environmentally allencompassing to reduce poverty and build common wealth for today's populace and to endure to meet the desires of upcoming generations. Sustainable development is supposed to be fruitful with resources that are consciously organized to offer equally rapid and long-standing paybacks for persons and the earth thriving in prosperity (World Bank, 2013). The pillars of possible expansion are three in numbers included social consideration, economic development, and natural stewardship.

Concurring to Bettley and Burnley (2008), sustainability is a progressively significant issue for a wide extends of organizations and thus sustainable administration procedures are of immense importance. Moreover, since numerous sustainability impacts are unequivocally affected by operations administration choices, the operations administration work must grasp the necessities of sustainable administration.

\subsection{The Challenges of Human Resources and Human Capital Management}

The determination of the human component of the factors of production makes the difference amongst triumph as well as dissatisfaction. Be that as it may, the importance of this reality is misplaced on numerous organizations emerging to a great extent from our conventional culture where individuals are classified as simple assets, and in fact alternative kind of instrument to be planned, organized, and the way that connotes the referral to the use of the terminology commonly understood as the "Human resources.' Hence, an attempt is made to realize that human persons need agreeable connections and administration ought to work out affectability to staff sentiments and support them through the provision of an awesome upkeep of their well-being. Administration need to have the obligation to provide a working environment that encourages enrollment, improvement, and inspiration of individuals in the various work teams.

The esteem of human assets starts from the accumulation of the requisite information and abilities by the individual that is commonly referred to as competence, and secondly, his demeanor classified as 
inspiration and conduct, and thirdly, the mental capacity of the individual categorized as advancement and adjustment. The essential challenge of Human Capital administration has is the process of planning the in-house structures that can persuade the individuals, in a particular way that supports upgrading the worker's productivity in the direction of fulfilling of the organizational goals.

\subsection{The Advent of the Knowledge Workers}

As a result of the increasing preference on consumer-quality awareness in the international business setting and the improved usage of new tools, a new form of employee has appeared from the economizing and down-sizing regime of the 1980s and the 1990s. De Lacy (1999) stated that the fresh workforces are categorized as "knowledge workers" and these categories of workers are endowed with some notable features that could have included the high level of their skills, qualification, training, and their experience in the emergent areas of business. Prominently, these employees are able to handle deal transactions of extraordinary degree of intricacy and improbability that would need a high grade of conscious decision making, judgementally.

Additionally, reminiscent of the new knowledge-driven environments of the 1990s, the concept of guarantee to offer the required service has been reshaped to shield the preservation of knowledgeable investment or the 'corporate memory' is presently understood to be reliant on on employee dedication and contentment. Consequently, the intellectual wealth of organisations is the ideas and long period of practice by the employees which the administration attempts to arrange and strengthen to yield superior organisational value.

\section{Research Methodology}

According to Kumar (1996), research is a structured inquiry that utilizes an acceptable scientific methodology to solve problems and create new knowledge that is generally acceptable. Research can be quantitative or qualitative, according to Cresswell (2013).

\subsection{Research Design}

This study is qualitative in nature and had adopted the use of theoretical and conceptual approaches that also integrate a reference list review and citations to realize the desired aims. Ran and Leeuwen (2002) said that literature reviews create the avenue to produce information from the results of study already published on the subject matter. Accordingly, this research work was advanced by choosing articles from accessible databanks that dealt with issues on sustainable procedures, processes, and practices implemented in the business area.

\subsection{Secondary Data}

According to Saunders, Levis and Thornhill (2007), secondary data comprises raw data which have been collected for other reasons. This suggests that the information been sought is existing and accessible and only needs to be removed by the researcher (Kumar 1996). Secondary research affords the roots for supporting and elucidating the questions (Ghauri and Gronhaug 2005). Secondary data also include data stored in the organization in the form of records/accounts, journal/periodicals, audio and video recorded resources, all in an effort to acquire past and other forms of information (McGivern 2006; Kumar 1996).

The situation where massive quantities of data are being assembled and banked by researchers globally, the convenience of exploiting current data for research study is assuming a wider acceptance (Andrews, Higgins, Andrews, Lalor, 2012; Schutt, 2011; Smith, 2008; Smith et al., 2011). The view here is that secondary data study and usage is a worthy method to employ in the course of the study after a meticulous or scientific procedure is adhered to.

\section{Analysis/ Discussion of Results}

Due to the fact that sustainability impacts are greatly supported by operations management judgments, it therefore behooves on the operations managers to adopt the principles of sustainable management 
strategies in the course of carrying out their responsibilities. The approach has ramifications on the resolutions taken and on the processes associated with all aspects of operations management including the strategic options available, designing options, as well as the planning/control, and the desired level of development. For instance, the proper environmental and social performance goals, objectives, and pointers need to be incorporated with the quality, cost and the addition of predictable performance trials. The figure below shows the schematic diagram of operations management decision areas.

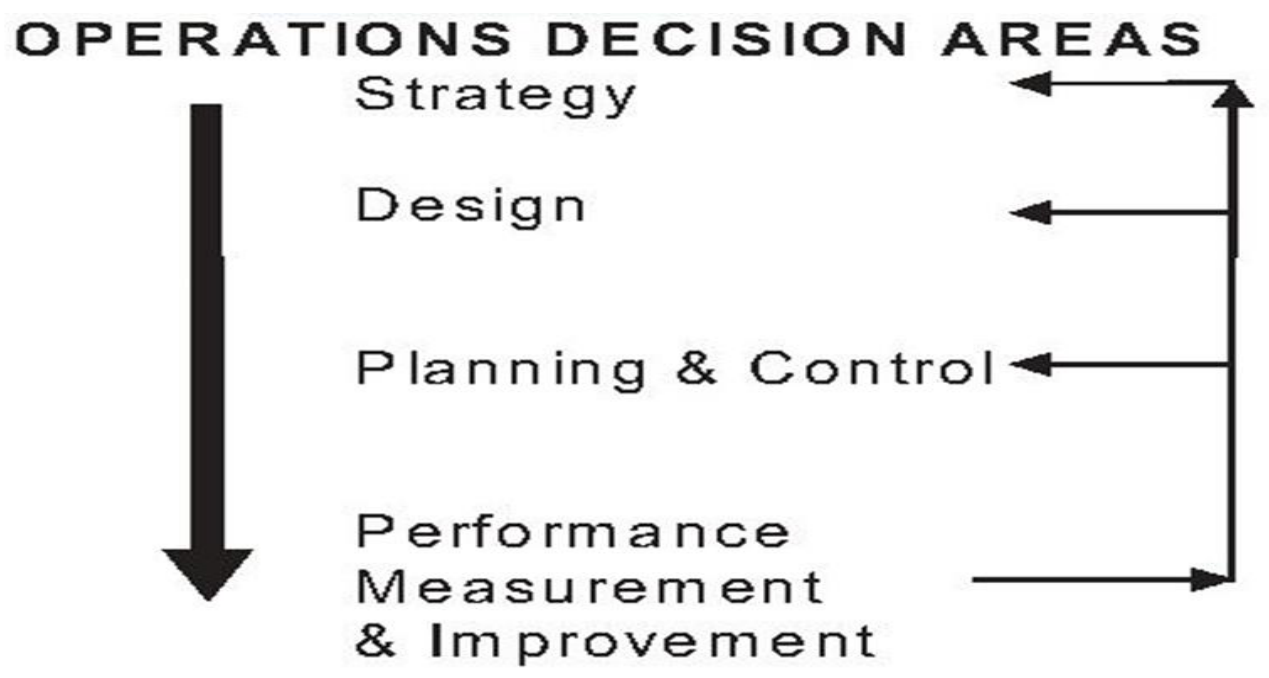

Source: Bettley \& Burnley (2008)

According to Stevenson (2015), operations management is the portion of a business enterprise that is in charge of manufacturing goods and offering services, and making sure that those goods and services reach the targeted consumers in the best form and with the anticipation of satisfying those target audience. Goods are the items that are made from raw materials through the manufacturing processes that could include assemblies and sub-assemblies. Services are the activities that provide some mixture of time, location, form, or psychological value. For instance, services are offered like all written materials we read, the films shows we patronize in the cinema, the electronic messages we sent and receive, and the medical treatment offered in hospitals, involves one or more operation functions of the organization.

\section{Conclusion and Recommendations}

Conclusively, and in making reference to the various sustainability studies, the results, and their remote origins, it empirically lay directly and to some extent on the operations executive domain. Correspondingly, operations pronouncements and undertakings have a weighty bearing on the majority of the broader concerns of sustainability that are related with working circumstances and the processes that covers the internal and other external fringes in the supply chain.

Consequently, this study recommend as per the listed below:-

- $\quad$ Firstly, the nature of sustainability itself has to be understood and explored by organizations.

- The latitude of operations services should be determine in order to support sustainability management on the basis of its relationship with the human resources available for utilization in the organization. This, therefore, gives the platform for a discourse on how the sub-divisions of operations administration can be structured in such a way to accommodate sustainable practices and processes.

- Organizations need to become more well-organized and effective in the whole manufacturing methods and systems, in commercial undertakings, in a comprehensive management of quality control (Total Quality Management), and in the overall facets of transformation the structure to accomplish excellence in standards of goods and services that can compete favourably in the markets.

- Organizations must have the obligation to plan and implement a comprehensive and unified 
tactic to human assets administration and environmental challenges. Supervising managers must have to reconsider their role, specially their responsibility in the encouragement of their organizations to accept and implement practices that encourage the backing of sustainability practices in all its ramifications.

- On operations supervision and environmental anxieties, worldwide heating and environmental degradation have had an heightened effect on the process of business operation, and consequently it has a direct link with the workings of operations management and environmental issues. Therefore, stricter environmental guidelines and principles, mostly in developed countries ought to be enforced.

\section{References}

Afiouni, F. (2013). Human capital management: a new name for HRM. International Journal of Learning and Intellectual Capital, 10(1), pp. 25-25.

Andrews, L., Higgins, A., Andrews, M. W., \& Lalor, J. G. (2012). Classic grounded theory to analyse secondary data: reality and reflections. The Grounded Theory Review, 11(1), 12-26.

Baron, A. \& Armstrong, M. (2007). Achieving value added through people. London. Kogan Page Limited.

Bettley A., Burnley S. (2008).Towards sustainable operations management integrating sustainability management into operations management strategies and practices.

Misra, K.B. (Eds), Handbook of Performability Engineering. Springer, London.

Buchanan, D. \& Huczynski, A. (2004). Organization behaviour: an introductory text 5th ed. Harlow: Prentice-Hall.

Carroll, A. B. (1991).The pyramid of corporate social responsibility: toward the moral management of organizational stakeholders. Business Horizons; 39-48.

Chatzkel, J. L. (2004). Human capital: the rules of engagement are changing. Lifelong learning in Europe, 9(3), 139-145.

De, L. (1999). Understanding the knowledge worker. HR Monthly, February. Ehrenberg, R.G. \& Smith, R. S. (2015). [online]. Retrieved from http://www.sss.wisc.edu/-walker/wp/wpcontent/uploads/2012/ehrenberg- smith-ch9.pdf.

Elkington, J. (2001). The triple bottom line for 21st-century business. The Earthscan Reader in Business and Sustainable Development, 20-43.

Ghauri, P, N., \& Grønhaug, K. (2005). Research methods in business studies: a practical guide. PrenticeHall. Pearson Education.

Gillet, C. (2011). 'A study of sustainability verification practices: the French case', Journal of Accounting \& Organizational Change, Vol. 8, No. 1, pp.62-84.

Gollan, P. (2000). Human resources, capabilities and sustainability. In Dunphy, D., Benveniste, J., Griffiths, A. and Sutton, P. (Eds), Sustainability: The corporate challenge of the 21st century, Allen Unwin, Sydney, 55-57.

Graham, H. T. (1978). Human resources management, 2nd ed. Plymouth: MacDonald \& Evans.

Jabbour, A.B.L.S. \& Jabbour, C.J.C. (2009). 'Are supplier selection criteria going green? Case studies of companies in Brazil', Industrial Management \& Data Systems, Vol.109, No. 4, pp.477-495.

Johnston, M. P. (2014). Qualitative and quantitative methods in libraries (QQML) 3:619 -626.

Jones, D .A. (2015. The challenges of corporate social responsibility/sustainable development. [PowerPoint Presentation]. Robert Gordon University, Aberdeen Business School. Retrieved from http://campusmoodle.rgu.ac.uk/pluinfile.php.

Kumar, R. (1996). Research methodology: a step-by-step guide for beginners. Melbourne: Longman Australia.

Olaniyan, D. A. \& Okemakinde, T. (2008). Human capital theory: implications for educational development. European Journal of Scientific Research. Euro Journals Publishing. 24, 157-162.

McGivern, Y. (2006). The practise of market and social research: An Introduction. 2nd ed. PrenticeHall. Pearson Education.

Neves, Tainan \& Drohomeretski., Everton \& Gouvea da Costa., Sergio \& Pinheiro de Lima., Edson. (2014). Sustainable operations management: Practices and measures in the food industry. International Journal of Advanced Operations Management. 6. 335. 
10.1504.

Payne, D. M., \& Raiborn, C. A. (2001). Sustainable development: ethics support economics. Journal of Business Ethics 2001; 32:157-168.

Porter, M. \& Linde, V. D. (1995). Green and competition-ending the statement, Harvard Business Review, Harvard Business School Publishing Corporation. September-October, 120-134.

Ran, A.F.J. \& Leeuwen, T.N. (2002). 'Assessment of scientific basis of interdisciplinary applied research: Application of bibliometric methods in nutrition and food research', Research Policy, Vol. 31, No. 4, pp.611-632.

Saunders, M., Lewis, P., \& Thornhill, A. (2007). Research methods for business students. 4th ed. Prentice-Hall. Pearson Education.

Scerri, A. (2009). 'Accounting for sustainability: implementing a residential emissions strategy using an approach that combines qualitative and quantitative 'indicators' of sustainability', Management of Environmental Quality: An International Journal, Vol. 21, No. 1, pp.122-135.

Senyucel, Z. (2009). [online]. Managing human resources in the 21 st century. Retrieved from: Bookboon.com/en/hrm.ebooks.

Slack, N., Chambers, S. \& Johnston, R. (2003). Operations management. 4th ed. FT Prentice-Hall. Pearson Education Financial Times.

Stevenson, W.J. (2015). Operations management, 12th ed. New York McGraw-Hill Education,

Storey, J. (1978). Human resource management: artificial text. London. Routledge.

The World Commission on Environment and Development (WCED) (1987). Brundtland Report: Our Common Future, Australia. Oxford University Press.

Vinodh, S., Prasanna, M. \& Manoj, S (2011).'Application of analytical network process for the evaluation of sustainable business practices in an Indian relays manufacturing organization', Clean Technologies and Environmental Policy, Vol. 14, No. 2, pp.309-317.

William, J. S. (2015). Operation management. New York. McGraw Hill Education. Wilkinson, A., Hill, M. \& Gollan, P. (2001). The sustainability debate. Journal of Operations \& Production Management, 21(12), 1492-1502.

World bank. (2014).[online]. Retrieved from: http://data.worldbank.org/sites/default/files/wdi-2014book.pdf

World bank. (2014). [online]. Retrieved from: http://data.worldbank.org/indicator/NY.GDP.MKTP.KD.zg/countries/RG-PLCZ?display=graph. 